\title{
Silje Bergman \\ Utfordringer ved bruk og deling av visuelle uttrykk i en digital tidsalder
}

\begin{abstract}
Sammendrag
De siste tiårenes teknologiske utvikling av bilderedigering og bildedeling har forandret hvordan bilder brukes som medium i kunst, kultur og kommunikasjon. Dette fører med seg andre problemstillinger knyttet til bruk og bearbeidelse av bilder enn det som var vanlig før. Artikkelen tar utgangspunkt $i$ utfordringer loerere står overfor når de skal undervise morgendagens konsumenter og produsenter av visuelt materiale, og spør hva loerere må vore klar over og ta hensyn til $i$ sin undervisning, slik at elevene tilegner seg de verktøyene de trenger for å vore informerte, kritiske og ansvarlige $i$ sine handlinger. Artikkelen har som mål å presentere og åpne opp noe av kompleksiteten $i$ åndsverkloven, og brette ut ulike temaer som har betydning $i$ en visuell og digital tid, både $i$ en skolekontekst og $i$ samfunnet generelt. Teksten er fagdidaktisk, og problemstillingene er diskutert med utgangspunkt fra fagområdet kunst og håndverk.
\end{abstract}

Nokkelord: Åndsverkloven, opphavsrett, kunst og håndverk, didaktikk, danning, teknologisk utvikling, digital delingskultur, interpikturalitet.

\section{Introduksjon til et problemområde}

Å bli inspirert av andres tekst, bilde eller musikk er en naturlig og lovlig del av en skapende prosess. Det er et viktig gode å ta vare på, men det er også viktig å være klar over grensen mellom det å la seg inspirere og det å kopiere eller plagiere på en måte som utnytter andres åndsverk. I arbeid med tekst kan det ofte være fristende å låne formuleringer fra en annens tekst, og med musikk kan sampling eller remiksing av et lydspor være det som skal til for at låta skal fenge. Remiksing brukes også på det visuelle feltet, men der musikkulturen ser ut til å ha omfavnet kompleksiteten som nye digitale verktøy gir, virker det som opphavsrett på det visuelle feltet ikke gjør det i like stor grad. Det er ofte vanskelig å bruke andres visuelle verk som bidrag til utvikling av felles kultur, ikke fordi all bruk er ulovlig, men fordi loven forutsetter skjønnsmessige vurderinger.

Denne artikkelen konsentreres omkring utfordringer ved bruk og bearbeidelse av visuelle uttrykk i en skolekontekst. Lærere møter i dag andre utfordringer i sitt utdanningsoppdrag enn for bare noen tiår siden, og skolen har et eget ansvar i å lære elevene hvilke måter de kan behandle andres åndsverk som inspirasjon i skapende arbeid.

Når opphavsrett og åndsverk diskuteres blant lærere, er det i hovedsak hva som kan vises i presentasjoner og hva som kan deles ut i kompendier som får oppmerksomhet. Lærere kan være opptatt av egen opphavsrett til undervisningsmateriale de har utviklet, og hvordan dette deles på skolens åpne og lukkede plattformer. For eksempel er Fronter, Canvas og ItsLearning plattformer der deling av materiale bestemmes av egne regler, og vil i noen sammenhenger regnes som den private sfære. Når materialet føres ut i det offentlige rom gjennom åpne plattformer, som for eksempel skoleblogger, YouTube, Instagram og Facebook, vil det reguleres av åndsverkloven. Det er viktig å være oppmerksom på disse forskjellene i en skolehverdag på et generelt plan, men i tillegg til dette er det også viktig hvordan elevene erfarer opphavsretten, og beskyttelsen av det de har laget selv. Viktige temaer i denne sammenhengen 
er hva som definerer et åndsverk, hva slags beskyttelse åndsverkloven gir, og hvordan andres åndsverk kan brukes som inspirasjon til eget skapende arbeid.

Fremveksten av internett og mulighetene for å kopiere som teknologien har åpnet for, har på mange områder økt intensiteten, og endret kreativiteten i hvordan vi jobber med en skapende prosess. Kopiering kan ikke kontrolleres i en digital tidsalder på samme måte som før. Alt er lett tilgjengelig, enkelt å kopiere, manipulere og publisere.

Det er et økende fokus på hvordan lærere formidler opphavsrettsregler i klasserommet. Gjennom to artikler i 2017 i det fagdidaktiske tidsskriftet for kunst og design i skolen, FORM, ble læreres rolle belyst, og hvordan de kan være gode formidlere av holdninger til bruk av andres bilder. Peter Haakonsen trakk frem digital dømmekraft i de grunnleggende ferdighetene, med kunst- og håndverksfag som utgangspunkt. Han konstaterte at elever trenger kunnskap om hva de kan og ikke kan bruke av bilder de finner på internett, og sier lærere må gå foran som gode rollemodeller og bruke lisensierte bilder (Haakonsen, 2017). Ingeborg Stana var i den andre artikkelen forbauset over hvor mange som «betrakter de praktiske konsekvensene ved det opphavsrettslige vernet som unødig kronglete» (Stana, 2017, p. 12). Hun påpekte at dagens og fremtidens undervisning i større og større grad vil benytte digitale læremidler, og at lærere derfor har et pedagogisk ansvar for å utvikle digitale ferdigheter hos sine studenter. I likhet med Haakonsen la hun vekt på riktig praktisering av åndsverkloven når lærere behandler verk $\mathrm{i}$ undervisningen. Stana avdekket også at det ofte syndes mot skolens danningsideal på dette feltet: «Dessverre møter jeg til stadighet på undervisningsmateriell med bilder og illustrasjoner uten navn på opphaver» (Stana, 2017, p. 13). Haakonsen og Stana har viktige argumenter, og gir fagfeltet et klarere definert mål om å utvikle helt nødvendige ferdigheter i en visuell og digital delingskultur. Men her er det et behov for å nyansere problemstillingene. Lærernes bruk av bilder i undervisningen er viktig, men å forenkle løsningen ved å kun velge lisensierte bilder frarøver elevene en mer aktiv form for læring, og læring for fremtiden.

Som forsker på disse spørsmålene møter jeg mye usikkerhet blant lærere om hva som er lov til å gjøre med bilder i skolesammenheng og ikke. Det er blant annet vanskelig å vite om elevenes arbeid kan stilles ut lovlig hvis det finnes spor av andres verk i dem. Det er også ofte usikkerhet knyttet til hvem ansvaret faller på, og hva konsekvensene blir, hvis verk blir ulovlig delt $\mathrm{i}$ åpne fora.

\section{Forskningsspørsmål og metodisk grep}

Denne artikkelen er skrevet med bakgrunn i fagfeltet kunst- og håndverksdidaktikk. Med konteksten beskrevet over har det vært hensiktsmessig å utrede bestemte temaer for å skape en helhetlig forståelse av problemfeltet. Dokumentanalyse (Duedahl, 2010) og kvalitativ tematisk analyse (Johannessen, 2018) har blitt brukt ved gjennomgang av fagtekster, vitenskapelige artikler og paragrafer fra åndsverkloven, som er relevante sett $\mathrm{i}$ en kunst og håndverk- og skolekontekst. Med konkrete caser og bildeeksempler, fra inn- og utland, vises og diskuteres problemstillinger uten å gå inn i juridiske definisjoner utenfor eget fagfelt. Tematisk analyse har vært til hjelp for å operasjonalisere og skape orden i kaos (Johannessen, 2018, pp. 31, 40) der gråsoner i lovteksten møter fagfeltet kunst og håndverk. Fra en kvalitativ forskningstradisjon sees analyse og diskusjon i relasjon til læreplan, didaktikk og skolens holdnings- og dannelsesmandat. Målet med å brette ut ulike problematikker i denne formen, er å presentere kompleksiteten i åndsverkloven knyttet til en visuell delingskultur og digital hverdag i skole og samfunn.

Problemstillingen blir derfor: Hvilke utfordringer skaper opphavsrett $i$ en digital delingskultur for bruk av andres visuelle åndsverk, med scerlig relevans for dagens kunst- og håndverksfag?

Gjennom teksten presenteres to hovedtemaer som inngang til problemstillingen. Det første er å belyse lovverkets beskyttelse av åndsverk, det andre er å se nærmere på skolerelevante utfordringer som oppstår i situasjoner der elevers arbeid kommer i konflikt med slike regelverk. Det trekkes ulike eksempler inn for å konkretisere utfordringene i praksis. Et 
annet mål med teksten er å sette utfordringer med inspirasjon og kopiering på dagsorden, som et slags tosidig fenomen i det å skape nye visuelle uttrykk.

\section{Problemområde digital hverdag og delingskultur}

\section{Digital teknologi gir tilgang, gjor det lett å bruke, og gjor det lett å dele}

Datamaskiner har vært vanlig i privat eie i et kvart århundre, og har gjort det mulig for alle å kopiere fra andre menneskers arbeid, med sin egen datamaskin som arbeidsverktøy. Klipp og lim er en helt naturlig integrert del av vår arbeidsprosess i dag, og det utvikles stadig ny programvare for å manipulere bilder. Enhver bruk av det som finnes på internett innebærer kopiering. Rent teknisk lages det en kopi for hver gang et bilde gjengis på en dataskjerm. Med denne enkle men samtidig så komplekse handlingen kopieres, brukes og skapes det nye verk som igjen tar del i en virtuell kulturell samtale, jf. avsnitt om remiks på side 11. Mulighetene det nye mediet gir har gjort det mer naturlig å utforske slike delingsprosesser.

Internett og datamaskinenes programvare har ikke bare gjort det enklere å finne, kopiere og bearbeide andres arbeid, men har også gjort det lett å publisere digitalt materiale. Alle kan ha sin egen publiseringskanal for både visuelle, auditive og audiovisuelle ytringer, og med dette følger et ansvar for å forstå hvordan vi kan og ikke kan bruke andres verk.

Den verdensomspennende delingsplattformen som internett er i dag, og som er resultat av den teknologiske utviklingen, er en viktig del av de unges sosiale verden. I tillegg kan det være vanskeligere å skille mellom privat og offentlig i dag enn det var før internett ble brukt som sosial arena. Å gjøre et verk tilgjengelig på en delvis lukket plattform trenger ikke være problematisk, men når hvert medlem $\mathrm{i}$ denne gruppen igjen sprer verket $\mathrm{i}$ sine sosiale delingskanaler, vil det raskt være delt i det offentlige rom.

Med deling i sosiale medier reises mange problemstillinger knyttet til for eksempel kompromitterende bilder og personvern. Utfordringen i forhold til det åndsverkloven regulerer, og som er fokus i denne artikkelen, kommer i det øyeblikk man har laget noe basert på et vernet åndsverk, og bestemmer seg for å dele det med andre. De neste sidene vil belyse hva åndsverkloven vektlegger.

\section{Lov om opphavsrett til åndsverk}

I Norge har vi europeisk opphavsrett. Dette er en menneskerett, underlagt FNs menneskerettighetserklæring artikkel 27:2 (FN, 1948). Opphavsretten definerer hva som gir et arbeid vern som åndsverk, og den gir to typer rettigheter til den som har skapt verket: ideelle rettigheter og økonomiske rettigheter. Disse er nedfelt i Lov om opphavsrett til åndsverk (Åndsverkloven, 2018), som oftest refereres denne til som åndsverkloven eller opphavsretten.

Lovteksten har en kompleksitet i måten den er bygget opp, for at den skal kunne fungere i møte med ulike former for åndsverk. Samtidig skal den ta vare på to av samfunnets ulike behov. På den ene siden skal loven sørge for at opphaveren har rådighet og kan «høste fruktene» (Torvund, 2017) av det han selv har skapt, og på den andre siden skal loven stimulere til at nye verk kan oppstå. Det følgende vil peke på relevante paragrafer for de problemstillingene artikkelen tar opp. For en grundigere presentasjon av åndsverkloven se: (Hannemyr, 2017; Rognstad \& Lassen, 2009; Torvund, 2012, 2017).

\section{Andsverk}

Ifølge loven er et åndsverk litterære, vitenskapelige eller kunstneriske verk av enhver art og enhver uttrykksmåte og uttrykksform. For å bli vernet som åndsverk må verket møte visse krav. Alle kravene må oppfylles for at verket skal kunne vernes basert på en rettslig oppfatning. For det første må verket være skapt av et menneske, og ikke av naturen alene (Rognstad \& Lassen, 2009, pp. 78-79). Verket må være en nyskapning og ha verkshøyde. Skaperen av et åndsverk kalles opphaver, og har opphavsrettighetene til verket.

Åndsverkloven slår fast retten til beskyttelse av det man har skapt, men den beskytter ikke vernede verk mot at andre lar seg inspirere. Alle kan bli inspirert av de kunstneriske verk 
som omgir oss. Lite skiller ofte det å bli inspirert av andres verk fra å kopiere det, og kopiering er ikke nødvendigvis ensbetydende med tyveri av en annens verk. En dobbeltfrembringelse kan også være lovlig etter åndsverkloven (Rognstad \& Lassen, 2009, p. 134). Enkelte ganger er det mulig å få den samme ideen som en annen har hatt, eller å lage noe som allerede finnes, uten engang å ha sett det. Bearbeidelse av åndsverk er heller ikke brudd på opphaverens rettigheter i alle sammenhenger. Lovteksten selv byr ikke på definisjoner av ulike typer kopiering som er mulige å rette seg etter. For å forklare kan det være mer hjelp i å se til for eksempel en dom i Høyesterett som omhandler opphavsrett til Il Tempo Gigante: «Bearbeidelse foreligger når en ny opphaver skaper en ny versjon av et eldre åndsverk, slik at verket i den nye utforming fremtrer som resultat av en skapende åndsinnsats fra både den nye og den gamle opphaverens side» (HR-2017-2165-A, 2017`, avsnitt 69). Det er også mulig at bearbeidelse av et verk fører til at en nyskapning og et selvstendig verk oppstår. For å forstå forskjellen mellom bearbeidelser og selvstendige åndsverk kan det være nyttig å først se på enerettsbestemmelsen i åndsverkloven (Åndsverkloven, 2018, §3).

§ 3. Opphavsretten gir innen de grenser som er angitt i denne lov, enerett til å råde over åndsverket ved å fremstille varig eller midlertidig eksemplar av det og ved å gjøre det tilgjengelig for allmennheten, i opprinnelig eller endret skikkelse, i oversettelse eller bearbeidelse, i annen litteratur- eller kunstart eller i annen teknikk (Åndsverkloven, 2018).

Opphaveren har altså enerett til å fremstille de eksemplarene han ønsker, og samtidig nekte andre å gjøre det samme (Rognstad \& Lassen, 2009, p. 150). Men åndsverkloven skal også tilrettelegge for at nye verk kan oppstå med utgangspunkt i noe eksisterende. For å sikre dette behandler $\S 6$ selvstendige verk:

$\S$ 6. Opphaveren kan ikke sette seg imot at andre benytter hans åndsverk på en slik måte at nye og selvstendige verk oppstår. Opphavsretten til det nye og selvstendige verk er ikke avhengig av opphavsretten til det verk som er benyttet. Den som oversetter eller bearbeider et åndsverk eller overfører det til en annen litterær eller kunstnerisk form, har opphavsrett til verket i denne skikkelse, men kan ikke råde over det på en måte som gjør inngrep i opphavsretten til originalverket (Åndsverkloven, 2018).

Ved første øyekast kan det synes enkelt å gjøre en slik vurdering. Men å bestemme om et selvstendig verk har oppstått er en vanskelig skjønnsmessig vurdering. Bearbeidelser av verk avgrenses mot nye og selvstendige verk, sistnevnte «står på egne ben med et individuelt uttrykk - en identitet - som er løsrevet fra originalen» (HR-2017-2165-A, 2017', avsnitt 73). Det finnes ingen definert regel for hvor mye som kan kopieres fra et visuelt verk, slik blant annet Kildekompasset.no og Skriftlig.info m.fl. veileder studenter og skribenter om bruk av sitat i tekst.

Lovteksten alene kan ikke brukes til å peke ut hvilke elementer i et bilde som er vernet. En hånd eller et tre, forgrunn eller bakgrunn. Opphavsretten trekker kun opp den ytre rammen for en kunstnerisk og estetisk vurdering av hva som er verk og hva som er kopi. En slik vurdering må altså bygge på materialets kunstneriske estetikk. Men kunstnerisk og estetisk forståelse har endret seg mye siden åndsverkloven ble innført, og tillater ofte mer enn $\S 3$ og $\S$ 6 eksplisitt formulerer. Det skal for eksempel være lov å skape nye verk med inspirasjon fra verk vi alle kjenner igjen. Det er verkets «individuelle egenart» (Hannemyr, 2017) som får vern, og den avgjørende vurderingen er hvor mye det nye uttrykket skiller seg fra det opprinnelige verkets estetiske uttrykk.

I noen kunstformer, som for eksempel collage eller remiksing av musikk, vil det være sammenstillingen av de ulike kopierte elementene som blir det nye verkets individuelle egenart, og det vil være dette den nye opphaveren får opphavsrett til. Når et verk forlater den private sfære vil det være vanskelig å kontrollere hvordan det blir brukt til å skape nye verk (Torvund, 2017). 


\section{Verkshoyde}

Verkshøyde $\mathrm{i}$ åndsverkloven betyr at et verk må ha oppstått gjennom en individuell og «skapende åndsinnsats» (Rognstad \& Lassen, 2009, p. 85). Hva åndsinnsats innebærer er ikke enkelt å vurdere, og lovteksten utdyper ikke videre. I den tidligere nevnte dommen fra Høyesterett, der Aukruststiftelsen anket avgjørelsen om opphavsrett til Il Tempo Gigante, formuleres det noe veiledende om hvordan jussen vurderer verkshøyde og åndsinnsats:

Når loven bruker formuleringen «skaper et åndsverk», henspiller det på at åndsverket må ha verkshøyde for å nyte opphavsrettslig vern. Denne terskelen innebærer at verket må være uttrykk for opphaverens originale åndsinnsats; det må være resultat av en individuelt preget skapende innsats, og ved denne innsatsen må det være frembragt noe som fremstår som originalt, (...) Jeg tilføyer at ordet «originalt» i denne sammenheng ikke innebærer et krav om nyhet, men at det må være skapt noe som har en viss grad av individualitet og kreativitet (HR2017-2165-A, 2017`, avsnitt 66).

Her blir ordet originalt trukket inn som en slags faktor for å vurdere verkshøyde. «Ved originalitetsbedømmelsen skal det tas hensyn til både enkeltelementer i verket og til verket bedømt som helhet, (...) Også en original sammenstilling av kjente enkeltelementer kan oppfylle verkshøydekravet» (HR-2017-2165-A, 2017', avsnitt 67).

En annen faktor som gjør vurderingen vanskelig er at åndsverk som begrep er rettslig, ikke estetisk. For å bestemme om verket har verkshøyde må man derfor vurdere verkets art og ikke dets kvalitet. Det gis ikke beskyttelse for en idé fordi dette ville medføre en begrensning av vårt «åndelige felleseie» (Rognstad \& Lassen, 2009, p. 89). Ideen er fri, ingen kan eie den. Åndsverkloven legger heller ikke beslag på fakta. For eksempel kan historiske fakta benyttes fritt av alle. Ingen får opphavsrett til kunnskap eller forskningsresultater. For enerettigheter til slikt materiale kan noen ganger andre lovverk, patenter eller lisenser nyttes. Forskningsetiske retningslinjer (NESH, 2016) vil for eksempel regulere hvordan forskningsresultater, data og ideer innenfor forskning kan brukes av andre. Det som får vern av åndsverkloven er den konkrete utformingen, og opphavsretten til en idé vil kun være mulig hvis denne betinges av selve formen. Ideer som funksjon vil aldri være åndsverk, kun den konkrete estetiske utformingen.

\section{Krenkelse}

Krenkelse, slik det brukes i denne teksten, er et juridisk begrep som viser til at noen har brutt de ideelle rettighetene $\mathrm{i}$ åndsverkloven, som å ikke oppgi opphaverens navn, eller å gjøre noe med et verk som setter det, eller den opprinnelige kunstneren i et dårlig lys. Beskyttelse mot krenkelse er en viktig ideell rettighet som åndsverkloven behandler i § 5 (2018). Spørsmål om det har skjedd en krenkelse beror på grensene mellom kopiering, etterligning, endring eller bearbeidelse på den ene side og nye og selvstendige verk på den andre siden (Rognstad \& Lassen, 2009, p. 133). Først må det avgjøres om verket som er brukt har verkshøyde, for har det ikke det vil det ikke være snakk om en krenkelse (Rognstad \& Lassen, 2009, p. 133). Hvis verket som er benyttet viser seg å ha verkshøyde må det undersøkes om selve bruken er et problem. Ikke all bruk av åndsverk er en krenkelse av opphavsretten.

Det skal blant annet være mulig å sitere fra kunstneriske verk, enten det er snakk om musikk, litteratur eller visuell kunst. Sitatretten er en viktig rettighet for å stimulere til at det skapes nye verk, og det er ofte en forutsetning for utvikling av kunstnerisk produksjon (Aakre, 2002, p. 93). Sitat kan også gjøres fra visuelle verk. Dette er vanlig i remiks og Mash-ups (Jugacaro, 2014; Lamb, 2007). 


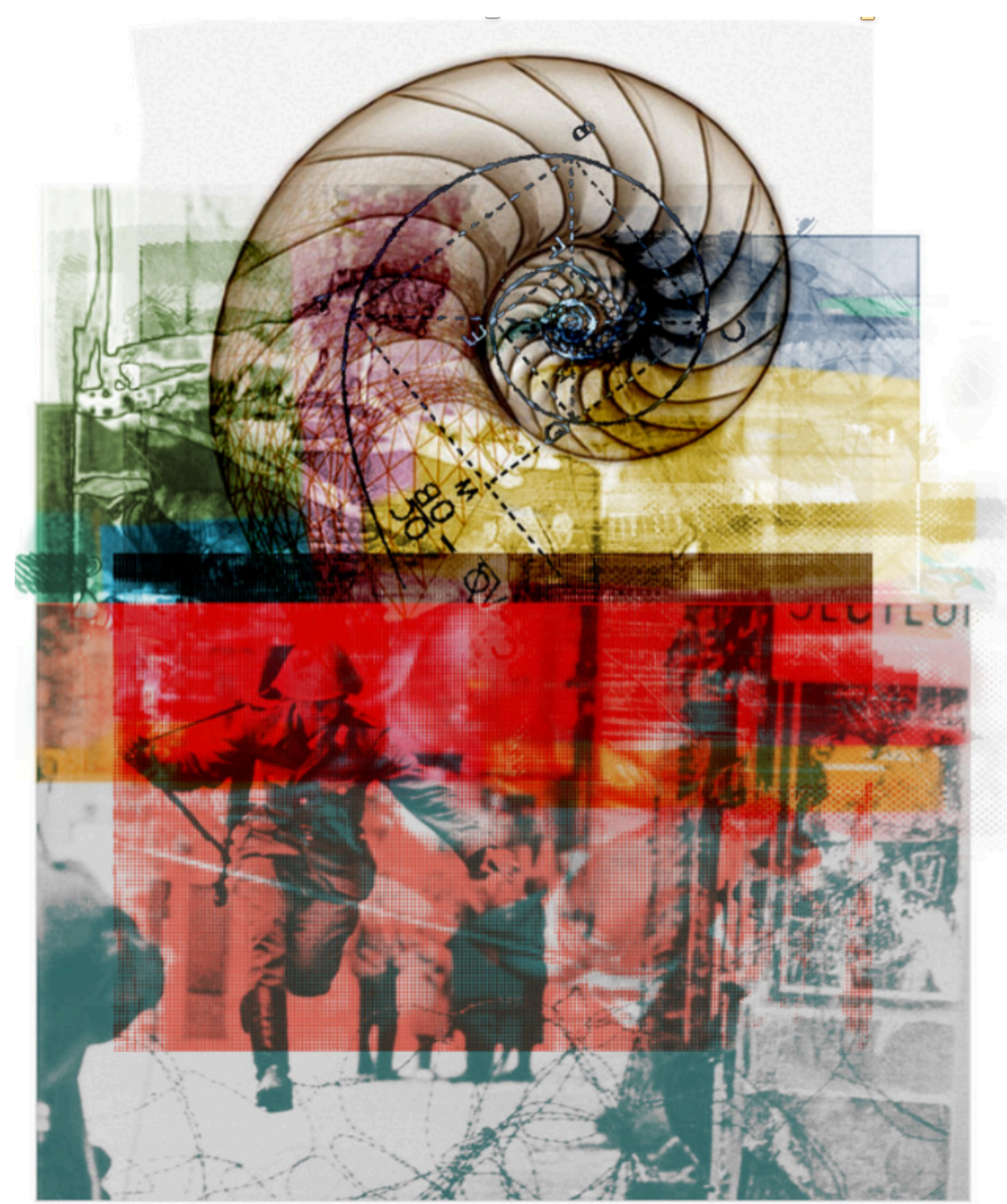

Bilde 1. Eksempel på Mash-up: Jugacaro, Fondo1vg, 2014. Gjengitt med tillatelse fra Jugacaro.

Mash-up brukes ofte om digitale mediefiler som henter innhold fra ulike eksisterende kilder, som tekst, bilde, lyd, video, animasjon, og setter dette sammen til en ny helhet. Rent visuelle Mash-ups, som i bildeeksempelet her (bilde 1), bruker eksisterende bilder som andre har skapt, og komponerer disse sammen til et nytt visuelt uttrykk, gjerne med et nytt budskap.

Adgangen til å publisere slike verk er uklar, men har mange likheter med sitatretten vi har $\mathrm{i}$ åndsverkloven. Retten til å sitere fra åndsverk behandles under Sitat (Åndsverkloven, $2018, \S 29)$. Sitering er anerkjent bruk som fremmer utvikling av verk. Men det er også viktig for å kunne kritisere og gjengi hva andre har formulert, og for å synliggjøre bakgrunnen for egen ytring. 


\section{Opphaverens rettigheter}

Åndsverkloven skal gi beskyttelse for de ideelle rettigheter og økonomiske interesser som knytter seg til et åndsverk. Ideelle rettigheter kan være navngivelse, som betyr at opphaverens navn alltid må gjøres kjent ved bruk av verket (Rognstad \& Lassen, 2009, p. 200), eller vern mot krenkelser, som betyr at verket ikke kan brukes på en slik måte at opphaveren eller verket blir stilt i et dårlig lys (Rognstad \& Lassen, 2009, p. 136). De ideelle rettighetene tilfaller bare den som yter den skapende innsats, og kan ikke overdras til andre. Et verk er beskyttet av åndsverkloven i 70 år etter opphaverens død. Etter dette «faller verket i det fri» (Torvund, 2012), som betyr at det kan kopieres og brukes av alle. Selv om et verk er fritt vil det fortsatt være vernet mot at andre bruker det på en krenkende måte. De økonomiske interessene åndsverkloven beskytter er ment for å gi opphaveren enerett til å tjene penger på verket, men skal også gi insentiv til utvikling av en kunstners virke (Kulturdepartementet, 2016-2017; Rognstad \& Lassen, 2009; Åndsverkloven, 2018).

Hva som er en opphavsrettskrenkende handling er med dette forsøkt utdypet, men det er fremdeles en vanskelig vurdering for lærere, studenter og elever som ønsker å bruke andres åndsverk. Loven gir ikke svar på hva som er for mye plagiat, eller selvstendig nok bearbeidelse av et verk. En skjønnsmessig analyse må gjøres for hvert enkelt tilfelle, og det må vurderes i hvilken grad verkene har det samme estetiske uttrykket.

\section{Lån og Fair Use}

Fair Use-doktrinen er grunnlaget for amerikansk opphavsrett og er dypt forankret i det amerikanske samfunnet (P. Aufderheide, Jaszi, P., 2011, p. 24). Denne bygger på et prinsipp om at det er lov å bruke/låne/kopiere opphavsrettsbeskyttet materiale så lenge brukens offentlige tjeneste er større enn det private tapet. Fair Use-beskrivelsen i amerikansk Copyrightlov gir ingen definisjon, men beskriver noen situasjoner der et slikt prinsipp kan følges, og henviser til fire faktorer som skal vurderes i det enkelte tilfellet (17-USC). Disse fire faktorene består av: 1) Purpose and character of use. 2) Nature of copyrighted work. 3) Portion used. 4) Effect of use upon potential market (17-USC, § 107).

Den første faktoren purpose and character of use fokuserer for det meste på om bruken er for kommersielt formål, og om den er transformativ. En transformativ bruk vil mer sannsynlig være Fair Use, og legger gjerne til noe nytt, med nytt uttrykk eller endret budskap. Med nature of copyrighted work må det undersøkes om originalverket er kreativt eller informativt. Mer kreativitet og originalitet i originalverket stiller et høyere krav til motivasjonen for å bruke det, for at det skal regnes som Fair Use. For å vurdere the amount and substantiality of the portion used vil den tredje faktoren beregne hvor mye av det opprinnelige arbeidet som er kopiert. I amerikanske domstoler er det vanlig praksis å se på om materialet som brukes er essensen av det nye arbeidet, ikke å gjøre en prosentvis utregning. I effect of the use upon the potential market ligger et hensyn til den originale opphaverens økonomiske interesse, og om denne kan forringes av at det kopieres fra verket. Amerikansk høyesterett vurderer særlig denne faktoren som betydningsfull i Fair Usespørsmålet (Caroll, 2007).

I Amerikansk Copyright og begrepet Fair Use finnes det mange likhetstrekk til våre låneregler. For eksempel behandler Copyright privat kopiering, og gjengivelse i forskning og kritisk vitenskapelig fremstilling (som vi finner i Åndsverkloven, § 26 og § 37). Men Fair Use og våre låneregler kan likevel ikke sidestilles. For å vurdere et verk med bakgrunn i de nevnte faktorene har lærere, bibliotekarer og andre brukere av opphavsrettsbeskyttede verk i USA kunnet støtte seg til en Fair Use-sjekkliste (Crews, 2015). Sjekklisten er ikke gjenstand for denne artikkelen, selv om det ville være interessant å se om noe tilsvarende kunne være til hjelp for lærere her hjemme. De fire omtalte faktorene danner strukturen i sjekklisten.

\section{Vi vender blikket mot det kunstneriske perspektivet}

$\AA$ reflektere og kommentere samfunnet har alltid vært en viktig del av kunstens rolle. Det er også en kanal for utfordrende ytringer, og vil man formidle noe er det virkningsfullt å trekke 
inn elementer alle kjenner igjen. På den annen side kreves det en bevissthet på hvilke etiske valg man må reflektere over $\mathrm{i}$ en slik prosess. I denne bevisstgjøringen har utdanningsinstitusjonene et ansvar. I det videre vil jeg se nærmere på hva slags kunstbegrep som legges til grunn ved vurderingen av verk. Kunstbegrepet $\mathrm{i}$ en postmodernistisk tid kan åpne for mer nærgående kopier. Hva som vil være lovlig beror på en refleksjon rundt begrepene som brukes om verkene. En slik refleksjon vil løpende være i utvikling, og for en lærer blir det viktig å forstå at det ikke skal være nødvendig med bakgrunn i juss for å gjøre en ansvarlig vurdering.

\section{Utfordringer med kunstbegrepet og holdninger til kunst}

Gjennom kunstens historie har synet på kunst endret seg mye, og i dag er barnehage og skole viktige formidlingsarenaer for hvordan barn berøres av og lærer å se og tolke visuelle uttrykk. Skolen har mulighet til å være motvekt til reklame, populærkultur og digitale massemedier, og kan påvirke barnas opplevelse av kunstneriske uttrykk. På videregående skole får mange kompetent undervisning i kunstfag som en del av utdanningen, og noen velger å studere kunst i ulike former i høyere utdanning. På dette nivået blir de selv en del av en kunsthistorisk kontekst, som utøvende, filosoferende eller formidlere av kunst og historie. Vi formes både bevisst og ubevisst til å dele et etablert kunstsyn påvirket av kunstteoretikere som har hatt innflytelse gjennom epokene. Vestlig kunstteori har opphav i teoriene til filosofene Platon og Aristoteles, hvor formålet med kunst var selve håndverket og etterligningen - mimesis. Under romantikken nærmet kunstbegrepet seg det vi bruker i dag, og Kants autonomiestetikk har på mange områder holdt seg til i dag (Svendsen, 2012).

Kunstens selvstendighet førte til et nytt estetisk paradigme som senere løftet frem andre sider enn kun det håndverksmessige og det mimetiske som kunstens formål. Den originale kunstneren og det særegne trådte frem i sentrum: «Kunsten handler nå om subjekter (kunstnerne) som skal lage suverene uttrykk for sin egen subjektivitet eller personlighet. Og verket vil være vellykket bare hvis dette uttrykket er autentisk» (Svendsen, 2012, p. 18). En slik autonomitanke preger fremdeles deler av kunstverden, men det kan synes å være et utdatert kunstnerbilde som åndsverkloven i sin tid ble skrevet for. Med modernismen spilte ikke lenger mimesis en vesentlig rolle, og i postmodernismen blandes det sammen og det oppstår helt andre verdier. Nå kan det kopieres, manipuleres og lekes med tradisjonen.

\section{Appropriasjon}

Digital teknologi har gitt oss måter å bruke og formidle verk på, som er vanskelig for lovene å regulere. Opphavsretten fungerte bedre for tidligere tiders rettslige utfordringer i kunstverden, da de store kunstneres stil og uttrykksform ikke like lett kunne kopieres (Nordell, 1997, p. 68), men i dag er problematikken annerledes. Den digitale teknologien har frembragt nye verktøy og skapt helt andre muligheter på det visuelle feltet. Gjennom dette er det utviklet kunstformer hvor kvalitet ikke nødvendigvis måles i hvor nyskapende noe er, og i hvilken grad det er originalt er vanskelig å bedømme. Appropriasjonskunst er en særlig utfordring (Vik, 2009). Kunstformen hadde sitt tidlige utgangspunkt i USA og 1980-årenes postmodernisme. Kunstverkenes rolle er i denne tradisjonen å skape diskusjon om selve definisjonen kunst. Kunstnerisk appropriasjon utfordrer hvordan vi vurderer originalitet og hva som er den skapende handlingen. Metodene som brukes i appropriasjon er kanskje det mest kontroversielle med hele kunstformen. De bygger på å bruke deler av eksisterende verk med varierende grad av endring, eller til og med kopiere hver minste detalj i et bilde for så å presentere dette som et eget kunstverk. 

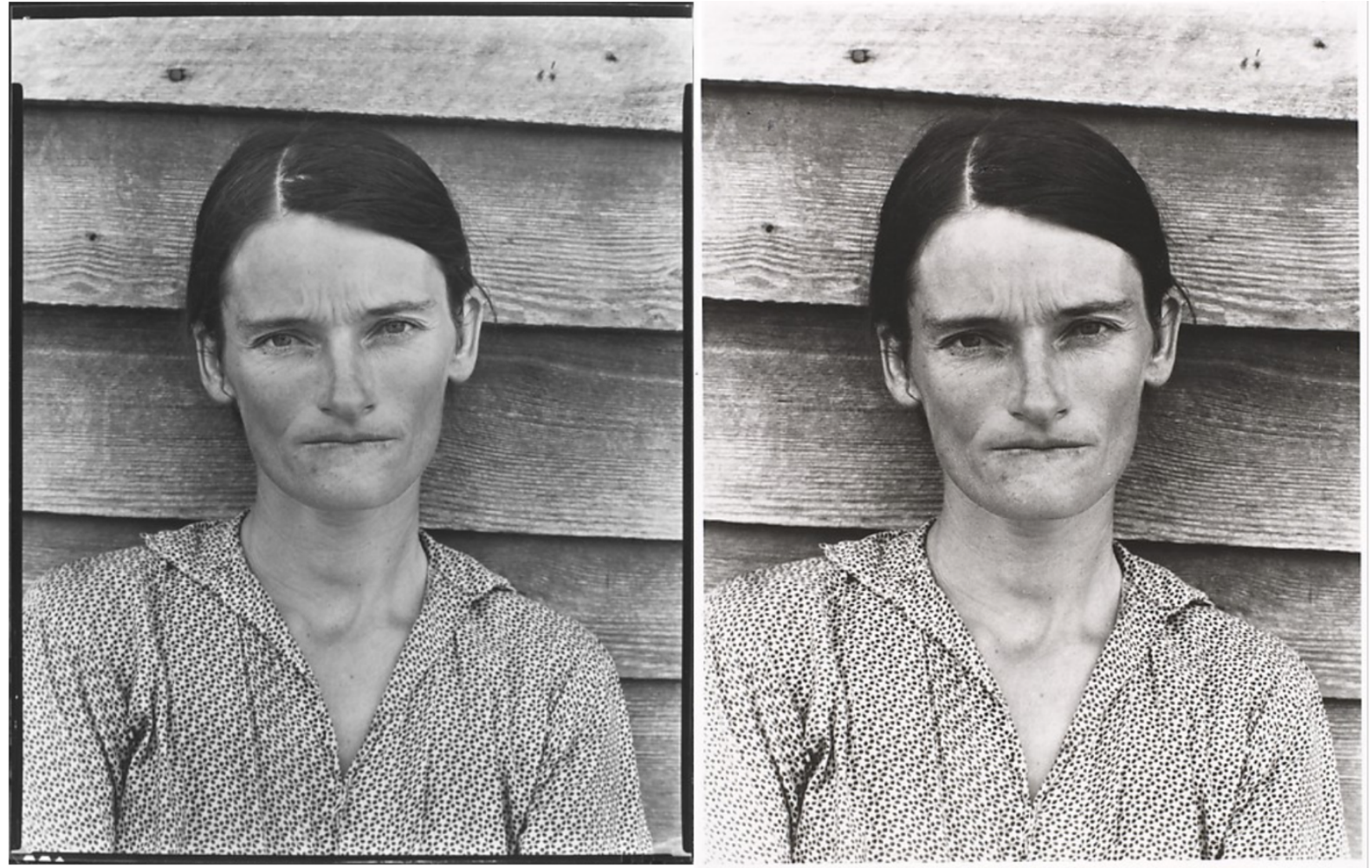

Bilde 2. Walker Evans, Allie Mae Burroughs, Hale County, Alabama, 1936. Bilde 3. Sherrie Levine After Walker Evans:4, 1981. Begge bilder gjengitt med lisens fra The Metropolitan Museum of Art.

Eksempelet over (bilde 3) viser Sherrie Levines appropriasjon av Walker Evans portretter fra 1936 (bilde 2). Evans viste utstillingen First and Last (Evans, 1936) med portretter av mennesker fra depresjonstiden. Levines utstilling 45 år senere viste serien Untitled, After Walker Evans (Levine, 1981), som besto av Levines avfotograferinger av bildene i utstillingskatalogen til Evans. Ved å re-presentere disse bildene som sine egne, er målet å få oss til å revurdere konvensjonelle forestillinger om kreativitet, originalitet og kunstnerisk opphav. Denne praksisen tar ofte opp spørsmål om hvordan kjønn, autoritet, og status hos kunstneren påvirker betydningen av et verk - hva som er originalen, og hva som er reproduksjonen. I dag tilhører ikke appropriasjonskunstens metoder bare 1980-årenes store navn som Andy Warhol, Barbara Kruger og Sherrie Levine. I dag er slike metoder og verktøy noe mange flere kan bruke, og ofte en naturlig del av den oppvoksende generasjons visuelle språk.

Den digitale teknologien og internett har for mange forandret selve ideen om det å skape noe. Litteraturkritiker Marjorie Perloff introduserer begrepet Unoriginal Genius (Perloff, 2010). Her beskriver hun en ny tendens hvor dagens forfatter ligner mer en programmerer enn et geni, og mener forestillinger om forfatteren som en romantisk, isolert figur er utdatert. Perloff fokuserer på hvordan ulike tekster veves sammen i en konstruksjon av nye tekster, og kritiserer ideen om at kunstnere skaper verkene ut ifra sitt eget originale hode. Hun mener at originalitet fremdeles finnes, men at dagens uoriginale geni lokaliserer det et annet sted, og presenterer det $i$ en annen form (Perloff, 2010, p. 21). Kunstneren fungerer som en konstruktør av nye historier gjennom å bruke det som noen andre allerede har skapt.

\section{Intertekstualitet og interpikturalitet}

I noen sammenhenger kan den estetiske opplevelsen av et kunstverk bli mer interessant av at det har referanser som peker ut over selve verket, og som henter noe fra en tradisjon eller en annen kunstner, eller noe som er visuelt gjenkjennelig. En tekst vil for eksempel leses og forstås i relasjon til andre tekster. Intertekstualitet brukes for å beskrive at leserens kulturbakgrunn og 
erfaringer, i tillegg til tekstens sjanger og referanser, legger grunnlaget for hva som kan leses igjennom teksten. Begrepet ble først introdusert av Julia Kristeva i 1966 (Kristeva, 1980). Det forteller at en tekst ikke oppstår fra én forfatters hode alene, men at tekster utvikles fra en samling eksisterende tekster. Kommunikasjonen som foregår mellom forfatter og leser vil være en blanding av relasjonen ordene har til hverandre, og relasjonen de har til tidligere tekster, «any text is constructed as a mosaic of quotations; any text is the absorption and transformation of another» (Kristeva, 1980, p. 66). Utfordringen med intertekstualitet er ofte at koblingene tekstene imellom kan være vanskelige å styre fordi forfatteren ikke har kontroll over hvilket utgangspunkt leseren har, eller hva denne har erfart og lest tidligere. På samme måte vil betrakteren av et visuelt kunstverk ta med seg erfaringer fra tidligere kunstopplevelser inn $\mathrm{i}$ tolkningen av nye.

For å favne denne problemstillingen innenfor et visuelt kunstbegrep har kunsthistoriker Jorunn Veiteberg lansert begrepet interpikturalitet istedenfor intertekstualitet. Helt tilbake i 1982 beskrev hun interpikturalitet som en type fenomen hvor alle bilder består av sitat, åpne sitat, indirekte sitat, lån og tyveri (Veiteberg, 1982). Hun var lei av at det selv på det visuelle feltet alltid er snakk om å lese, og at litteraturen blir førende for begreper. Interpikturalitet var et forsøk på å begrepssette den visuelle utgaven av for eksempel sitat, parafrase og homage. Begrepet slo ikke igjennom dengang, men Veiteberg er opptatt av at det representerer et kunstsyn der alle ting består av sitat. I et senere intervju sier hun: «Når vi kan gjenkjenne noe har vi straks mye mer å fortelle, et nivå er den umiddelbare opplevelse, andre nivåer er gjenkjennelse som er med på å gi et betydningslag til, et betydningslag som de får med seg gjennom lånet» (Bergman, 2012, p. 82). Sitat, eller indirekte sitat skaper med dette perspektivet en relasjon til det som kopieres, på en slik måte at vi kan tolke verket gjennom det vi kjenner igjen fra tidligere. Gjenkjennelsen er et vesensfenomen ved intertekstuelle eller interpikturelle verk, og er med på å gi verket mening.

I internasjonal sammenheng har interpicturality, som begrep for å beskrive relasjonene til tidligere verk, fått mer aksept enn her hjemme. Kubilay Aktulum skriver at det er mulig å overføre begrepet intertekstualitet til å gjelde en rekke andre kunstformer enn litteratur, som: «interpicurality, intermediality, intermusicality, intercinema, intertheatrality, interphotography etc.» (Aktulum, 2011, p. 3). Han definerer interpicturality i sin artikkel Interpicturality in Braun-Vega's Paintings, der det kommer frem at begrepet ble nødvendig på grunn av BraunVegas arbeidsmetoder (Aktulum, 2011). Han gjør flere deldefinisjoner, men essensen er at interpikturalitet er en funksjon der materialiseringen av et verk i et annet får fokus som refererende heller enn kopierende og plagierende. Ulike former for interpikturalitet kategoriseres videre, men felles er at bilder av denne typen har en relasjonell samtale med tidligere kunstnere og tidligere verk, eller tidligere kunstneres visuelle formspråk. Det interpikturelle i et verk kan være direkte eller indirekte transformasjon, imitasjon, eller satirisk, parodierende transformasjon. Hvordan bilder relaterer seg til andre verk kan være fra helt enkle referanser til andre verk, som en sitering av et element eller enkle allusjoner, og i andre ende kan hele det refererte bildet ta plass i det nye motivet. Andre tilfeller igjen kan bære preg av selv-interpikturalitet, at skaperen reproduserer egne verk eller bygger videre på egne arbeider (Aktulum, 2011).

\section{Regulering og kreditering i en remiks-kultur}

I likhet med interpikturalitet brukes remiks som begrep for å beskrive verk sammensatt av andre. Gjerne forskjellige medium i et verk, som lyd og video. Remiks har kanskje fått størst aktualitet i musikkens verden, der låter blir konstruert og satt sammen av spor fra eksisterende musikk. Problematikken som oppstår her ligner mye på utfordringene slik bruk skaper på det visuelle feltet. Reglene man møter ved sampling av et lydspor, har likevel ordninger som kan virke enklere å forholde seg til. Kanskje fordi de har vært prøvd flere ganger. Tvister på musikkfeltet har i mange år nådd medias oppmerksomhet og muligvis skapt en mer forståelig vei til hvordan man betaler for bruk av et verk, eller hvordan opphaver skal krediteres. For 
musikere, som er kjent med reglene ved å sample fra eller covre andres låter, er det ikke alltid opplagt at det også kreves betaling for å remikse en visuell representasjon i tillegg til audioverket musikeren har betalt for.

Et eksempel på sistnevnte er amerikanske Andy Baio, som ble saksøkt for å ha brukt og bearbeidet et fotografi av Miles Davis (bilde 5) (Baio, 2009b). Platen han laget skulle være en tribute til Miles Davis Kind of Blue. Han hadde forhandlet frem en avtale om å lage chiptune versioner av låtene på plata, og betalt vederlag for dette. Chiptune er også kalt 8-bit musikk, altså den type komputergenererte lyder som kjennetegner gamle dataspill. Men å bruke det tilhørende fotografiet av Miles Davis på coveret var ikke en del av avtalen, og han endte opp med å betale ca. 250.000 NOK for å ha brukt bildet til fotograf Jay Maisel (bilde 4) (P. Aufderheide, 2013; Jackson, 2012), enda det var en endret utgave av bildet.
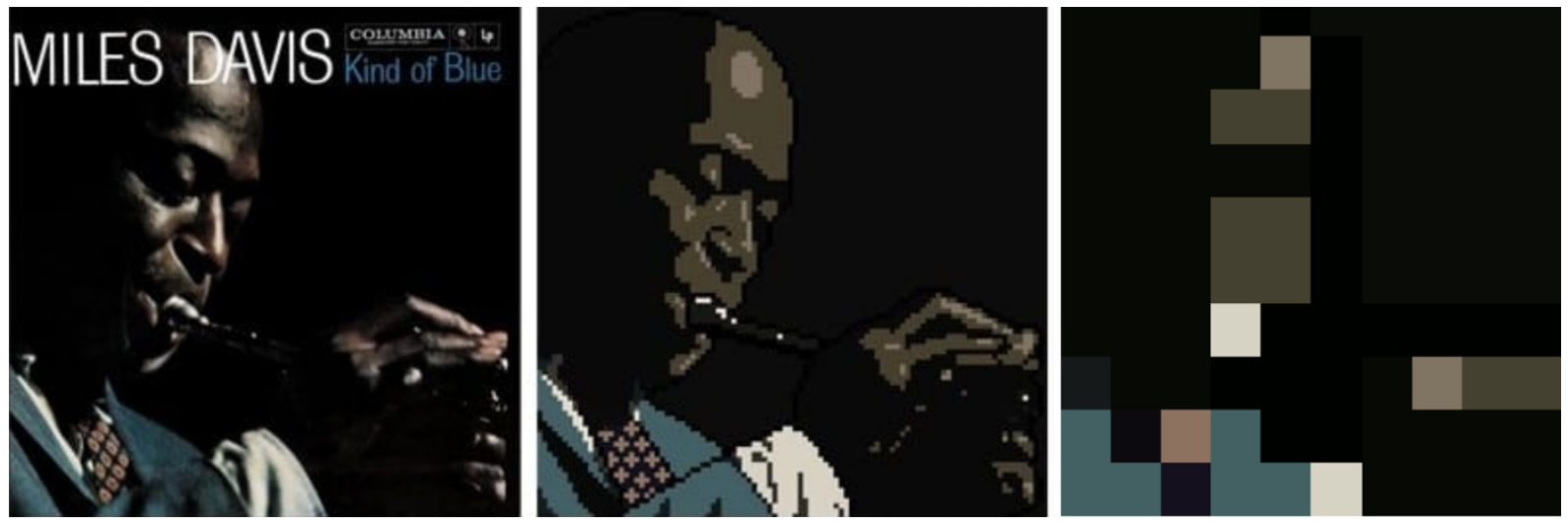

Bilde 4. Jay Maisel, Miles Davis, Kind of Blue, 1959. Gjengitt med tillatelse fra Studio Manager hos Jay Maisel Photography. Bilde 5. Andy Baio Various, Kind Of Bloop: An 8-Bit Tribute To Miles Davis' Kind Of Blue, 2009. Første coverbilde. Bilde 6. Andy Baio Kind Of Bloop Cover, 2009. Endelig coverbilde. Gjengitt med tillatelse fra Baio.

En musiker vil gjerne sette seg inn i hvordan opphavsretten fungerer i eget fagfelt. For å låne lydspor fra andres musikk betales det ofte faste satser til rettighetsorganisasjoner, og videre til opphaveren. Med utgangspunkt i et regulert musikkfelt kan det visuelle feltet oppleves som utfordrende, med tanke på hva slags bruk som vil utløse pengekrav. Det kan være vanskelig å vurdere om den visuelle bearbeidelsen til Baio har lagt seg for nært opp til sin inspirasjon. Linken til den digitalt miksede musikken er selvsagt viktig i eksempelet, men det interpikturelle i verket kan også stå for seg selv, som en slags ny stemme, som sammen med det opprinnelige fotografiet skaper en ny fortelling. Det interpikturelle i verket er vanskeligere å få øye på i den endelige utgaven av platecoveret til Kind of Bloop (bilde 6) (Baio, 2009a).

Grensene mellom eget og andres materiale kan mange ganger være så utflytende at det er vanskelig å se til åndsverkloven for å handle på en ansvarlig måte. Å tolke lovteksten gir ingen oppskrift på hva som er rett, og det kan bli kostbart å handle galt. Det er verdt å merke seg at en opphavsrettsdomssol ikke nødvendigvis er bedre til å vurdere kunstnerisk originalitet enn det en lærer eller kunstner kan være, noe også flere rettsavgjørelser på dette området understreker. Blant annet i den nevnte Il Tempo Gigante-saken ble utfallet endret i høyesterett (HR-2017-2165-A, 2017), og det samme i en omstridt sak fra USA der den øverste amerikanske domstolen snur helt rundt på dommen av Cariou vs. Prince (11-1197-2d-Cir., 2013). Appropriasjonskunstneren Richard Prince tapte mot fotograf Patric Cariou i tingretten for sin bruk og bearbeidelser av fotografens dokumentariske bilder. Dette er en viktig dom for det amerikanske kunstmarkedet, men den er foreløpig så ny at det er vanskelig å si hvilken virkning det har hatt på utøvelsen av kunst. Dommene bekrefter at dette er vanskelige vurderinger som i stor grad preges av skjønn, og den viktigste lærdommen herfra kan være å bli klar over hvilke 
regler man bryter når man har latt seg inspirere av eksisterende verk, og deretter har lyst til å dele det med andre.

Hvis denne delingen foregår på internett, for eksempel delingsressursen YouTube.com, vil det i mange tilfeller være YouTubes Content ID som griper inn og sletter materiale de mener bryter med opphavsretten. Content ID er en programvare som analyserer utgitte musikkverk og sammenligner disse med lydspor i videoer folk laster opp til sine YouTube-kanaler. Programmet filtrerer altså lyden i en remiks mot lyden fra de verk som finnes fra før, og hvis den finner likheter kan en remiks som er lastet opp til YouTube slettes i sin helhet, eller eieren kan varsles om at det er begått et brudd mot noens opphavsrett (Rostama, 2015). Remiksene kan ofte ligne sitater hentet fra ulike kilder og satt sammen i en ny visuell fortelling, men her er loven så uklart definert at folk sjelden forstår hvorfor de kreative arbeidene de har lastet opp til for eksempel YouTube blir fjernet. Stengte YouTube-kontoer er ofte et resultat av at inspirasjonen til et verk har vært gjenkjennelig, og den som har publisert ikke har kunnskap om reglene YouTubes Content ID filtrerer etter. Slike tilfeller kan fort gi opplevelsen av at kreativt arbeid blir sensurert.

$\AA$ måtte forholde seg til et altfor komplisert lovverk kan få moralske implikasjoner for den oppvoksende generasjon $\mathrm{i}$ en digital tidsalder sier den amerikanske grunnleggeren av CreativeCommons.org, Lawrence Lessig (Lessig, 2008). Han kritiserer den amerikanske opphavsretten og argumenterer mot lovens restriksjoner. Han mener den bygger på et kunstsyn fra en tid da teknologien ikke gav oss de mulighetene som er helt vanlige i dag (Lessig, 2007). Han fokuserer spesielt på hvor vanskelig det er for unge å forstå hva som er ulovlig og hvorfor, og sier at når én lov blir betydningsløs kan det skape negativ effekt på unges holdninger til lover generelt (Lessig, 2008).

Digitale medier får en større rolle og er i dag uforenlig med en åndsverklov med et gammeldags kunstsyn. Kenneth Goldsmith som underviser i Uncreative Writing mener opphavsrett bygger på forestillinger om at en kunstner skaper originale verk, kun ut ifra sitt eget hode (Goldsmith, 2011). Med faglig bakgrunn innen litteratur utfordrer han litteraturverdenens bruk av ny teknologi, blant annet med nettstedet UbuWeb.com. Prosjektene kan forstås som ledd på vei mot et endret kunstsyn, der forfattere kan skape originale verk av allerede eksisterende materiale. Den samme problematikken jeg knytter til det visuelle feltet.

Frem til nå har artikkelen brettet ut et problemfelt med utgangspunkt $\mathrm{i}$ to temaer: forståelse av lovverk, og bruk/bearbeidelse av andres kunstneriske verk. Ândsverkloven skal sørge for insentiver til at kulturell produksjon kan være fruktbart for den enkelte opphaver. Men det trenger ikke være en motsetning til interpikturalitet, remiks og Mash-Up hvor arbeidene har en relasjon til eksisterende verk, eller til postmodernistiske sjangre som appropriasjonskunst. I det følgende trekkes temaene videre og diskuteres i lys av skolens danningsmandat.

\section{Blikket fokuseres mot en skolekontekst}

Metoder for å sy sammen biter av eksisterende materiale er ingen ny trend i kunstverden. De kan på mange måter også sammenlignes med hvordan elever jobber med for eksempel digitale fortellinger og multimodale tekster i skolen. Men at det er vanlig gjør det ikke automatisk godt nok problematisert i skolens læreplaner. I min gjennomgang av litteratur som brukes i kunst og håndverk for grunnskole og videregående, samt det som vises til i emneplaner for lærerutdanninger i kunst og håndverk, har jeg ikke funnet kilder der spørsmål om ansvar og opphavsrett behandles sammen med elevenes bearbeidelser av andres visuelle åndsverk.

Blant vitenskapelige artikler og fagartikler finnes det tangerende problemstillinger som kan være interessante å se i sammenheng. To doktorgradsavhandlinger fra 2009 og 2011 studerer hvordan lærere i kunst og håndverk vurderer originalitet i elevers designarbeider. Her drøftes kopiering og re-design som aktuelle metoder i elevenes arbeider (Brænne, 2009, p. 144; Lutnæs, 2011, pp. 177-197). Brænnes funn peker på at det imiterende og det originale fremdeles sees på som motpoler for «re-designpraksis» og «originalitetsintensjoner» (Brænne 2009 p. 144) selv om noen av informantene er åpne for kopiering i en inspirasjons- eller læringsfase. Et 
fellestrekk hos Lutnæs' informanter er at begrepet kopi er negativt ladet når de beskriver kvaliteter i elevenes arbeider (Lutnæs, 2011, p. 177). Dette er interessante funn for spørsmål om originalitet i elevarbeider, men studiene vektlegger ikke hvordan inspirasjon eller lån av vernede verk kan utvikle forståelse av opphavsrettigheter. At jeg ikke har funnet forskning som eksplisitt ser på hvordan elever kan bearbeide eksisterende verk for å prøve ut og forstå grensene i åndsverkloven, behøver ikke bety at spørsmålene ikke diskuteres i klasserommet og $\mathrm{i}$ andre fora. Men at det $\mathrm{i}$ aktuelle læreplaner for kunst og håndverk, fra grunnskole til lærerutdanning, ikke er formulert. Mer praksisorientert forskning på undervisningsformer som øver elever i å bruke andres verk kreativt skapende og ansvarsfullt, kan styrke læreres faglige kompetanse og grunnlag for å drøfte problemstillinger som både elever og lærere kan støte på.

I noen fag er problemstillingene, og løsningene, mer konkretisert. Det er for eksempel godt innarbeidet at elever får innføring i korrekt kildehenvisning ved bruk og sitering fra litterære tekster. Den alminnelige oppfatning er at sitering i litterære tekster er korte, uendrede utdrag, som består av noen få setninger til noen få ord (Aakre, 2002, p. 28). Men for kunst og håndverksfeltet er ikke sitering fra visuelle kilder problematisert i samme grad (Bergman, 2012, p. 90; Utdanningsdirektoratet, 2012).

For lærere i design, kunst og håndverk er det ikke ukjent at elever ofte legger seg veldig nær den kunstner eller verk de inspireres av, uten å reflektere over en slik handling (Bergman, 2012). Blant annet viste en artikkel, i det tidligere nevnte tidsskriftet FORM, skoleoppgaver der elever etterlignet kjente kunstneres form og uttrykk. Formålet var i denne sammenheng å lære malingsteknikker og penselstrøk gjennom å kopiere for eksempel Munch og Matisse (Bergman, 2012; Jahr \& Jahr, 2010). Når elever har kopiert eller blitt inspirert av eksisterende verk, og utført dette i en lukket skolekontekst, vil ikke handlingen reguleres av noen åndsverklov. Men i det eleven vil vise sitt verk til venner utenfor skolens private sfære, og publiserer dette på for eksempel Facebook, er verket ute i det offentlige rom, og reguleres av lovene som finnes her. Hvis ikke elevene utfordres til å reflektere over denne handlingen, vil de ved å publisere arbeidene risikere å bryte reglene til et lovverk de ikke kan noe om. I motsetning til undervisning der lærere kun baserer materialet sitt på lisensierte bilder som ikke krever henvisning til opphaver, jf. Introduksjon på side 1, eller å ikke bruke andres bilder i det hele tatt, vil en slik viktig refleksjon bli helt uunngåelig når eleven selv må argumentere for valg og bruk av et bilde.

Visuelt inspirasjonsmateriale kan bearbeides på en slik måte at elever blir mer bevisste hvordan de bruker og bearbeider uten å krenke det originale materialet eller opphaver. Et sentralt problem, som lærere kan diskutere mer med elevene enn hva som gjøres nå, er hvordan man trekker grensen mellom verk basert på andres arbeid og eventuelle misbruk av andres arbeid (Bergman, 2012, pp. 89-90).

\section{Sporsmål om ansvar}

Ansvarsforhold i situasjoner der vernede verk er kopiert og delt vil ikke bestemmes av åndsverkloven alene, men av Lov om skadeserstatning (Skadeserstatningsloven, 1969). For lærere kan ofte en veiledningstjeneste som DelRett.no (utviklet av Norgesuniversitetet og Senter for IKT i utdanningen) gi mer forståelige og nyttige svar på slike problemstillinger fordi de allerede fokuserer på hvordan åndsverk brukes i undervisning.

Jeg presenterte en skolesituasjon for advokatene tilknyttet DelRett (DelRett.no, 2017). Den problematiserte ansvarsfordelingen der elever under den kriminelle lavalder publiserer opphavsrettslig vernet materiale på nett, i forbindelse med en skoleoppgave, uten å ha klarert dette med opphaver eller organisasjon først. Spørsmålene tok for seg om det er elev, forelder, skole eller lærer som er ansvarlig, og hva det vil innebære. I svaret ble det bekreftet at elever selv er ansvarlige for det de publiserer av kopiert materiale. Men selv om brudd på åndsverkloven er straffbart, vil ikke en elev under kriminell lavalder risikere bøter eller straff. Elever kan bli både erstatningspliktige og pålagt å fjerne det som er publisert hvis lovbruddet ender $\mathrm{i}$ en sivil sak. Men dette avhenger av at opphaveren til det opprinnelige verket har lidd et 
økonomisk tap på grunn av elevenes uaktsomme eller forsettlige handlemåte. Her er det skadeserstatningsloven som regulerer ansvarsgrunnlag og omfang: «Barn og ungdom under 18 år plikter å erstatte skade som de volder forsettlig eller uaktsomt, for så vidt det finnes rimelig under hensyn til alder, utvikling, utvist adferd, økonomisk evne og forholdene ellers» (1969, $\S 1-1)$. DelRetts advokat presiserte også at: «erstatningsansvar for barn under skolepliktig alder i alminnelighet ikke vil bli idømt og dette bare vil være begrenset til ekstraordinære tilfeller» (DelRett.no, 2017). Foreldre er altså ikke uten ansvar for hva barn de har omsorg for foretar seg på internett. Ansvaret i et tilfelle der mindreårige har brutt åndsverkloven vil bestemmes ut fra loven om skadeserstatning. Om ikke foreldre selv deltar i kopiering eller publisering av opphavsrettslig materiale, vil de likevel måtte svare for skade voldt forsettlig eller uaktsomt av deres barn. «Foreldre plikter å erstatte skade voldt av barn og ungdom under 18 år, såfremt de har latt det mangle på tilbørlig tilsyn eller på annen måte ikke har gjort det som etter forholdene er rimelig å kreve av dem for å hindre skadeforvoldelse» (Skadeserstatningsloven, 1969, § 12).

Da platebransjen ville stoppe uønsket deling av musikk på internett var det naturlig å gå etter foreldrene. Det er de som betaler for barnas internettlinje, og det er dem det er mulig å straffeforfølge (Osdal, 2014). Foreløpig finnes det ingen norsk rettspraksis der foreldre er gjort erstatningsansvarlige fordi deres barn har publisert visuelle arbeider på internett. Men det finnes en svensk dom der foreldre til mindreårige ble gjort solidarisk ansvarlige for ulovlige delinger på Instagram (Osdal, 2014).

Lærere risikerer altså ikke straffeforfølgelse i tilfeller der elevarbeider har brutt opphavsretten, så lenge de har forstått og kan formidle hvordan man handler ansvarlig $\mathrm{i}$ overensstemmelse med åndsverkloven, og ikke selv bidrar til offentliggjøringen av verket. Det er den personen som deler arbeidet i den offentlige sfære som utfører en ulovlig, og potensielt straffbar handling. Foreldre kan $\mathrm{i}$ visse situasjoner holdes ansvarlig når barn har utført en skadelig handling som foreldrene hadde ansvar for å forhindre. Men det er også skolens og læreres mandat å oppdra ansvarlige medborgere, med god dømmekraft og respekt for egne og andres kulturelle uttrykk.

\section{Digitale ferdigheter og skolens danningsideal}

Digitale ferdigheter er fagovergripende og skal inngå i de ulike fagenes læreplaner. Gjennom Kunnskapsløftet 2006 skulle digitale ferdigheter innføres som en grunnleggende ferdighet på linje med muntlige ferdigheter, lese-, skrive- og regneferdigheter (Utdanningsdirektoratet, 2012). Samlet utgjør de fem ferdighetene forutsetninger for elevens læring og utvikling i skole og samfunnsliv. Læreplanene for hvert fag har faste mål for hvordan de grunnleggende ferdighetene skal oppnås og utvikle elevens læring. Med dette faller en stor del av ansvaret på den enkelte lærer å skape en undervisningsform som utvikler ferdighetene. Ferdighetsområder i digitale ferdigheter defineres under stikkordene; tilegne og behandle, produsere og bearbeide, kommunisere og digital dømmekraft. Den siste, digital dømmekraft, innebærer å kunne bruke digitale verktøy, medier og ressurser på forsvarlig måte, og ha et bevisst forhold til personvern og etisk bruk av internett (Utdanningsdirektoratet, 2012). Ikke engang med et 2006-perspektiv på digital delingskultur ville denne formuleringen møte behovet for formidling av opphavsrettigheter.

For 15 år siden skrev Lars Løvlie om digital dannelse og teknokultur, at danningens dynamikk i det postmoderne samfunn finnes der «selvet og kulturen møtes» (Løvlie, 2003, p. 348). Dette skulle bety at pedagogikken hadde behov for å finne nye veier, åpne opp for å tenke på helt andre måter for å nå frem til tidens unge. Løvlie foreslo digital dannelse som en refleksjon over hvordan den digitale teknologien har innflytelse på mange områder av vår hverdag (Hagen, 2004; Løvlie, 2003), en bredere kulturell dannelse enn det de tidligere styringsdokumenter i skolen representerte. Den digitale bildeverden i dag er de unges hverdagskultur, og ungdom lever i grensesnittet. De formes som individ idet de former sin kultur og sin visuelle verden. Teknokulturen skaper møtepunktene, internett og sosiale medier 
gjør det mulig, og utdanningen bør se potensialet for refleksjon og ansvarliggjøring som ligger i det postmoderne samfunnet. Ser vi spor av disse perspektivene 15 år senere?

Kunnskapsdepartementet foreslo i Stortingsmelding 20 (Meld. St. 20 (2012-2013). (2013).) at den generelle delen av læreplanverket for Kunnskapsløftet skulle fornyes og tilpasses de utfordringene barn og unge møter i dagens samfunn. Endringene skulle reflektere hva som ser annerledes ut enn på begynnelsen av 90-tallet, og da spesielt hvordan digital kommunikasjonsteknologi har endret sosiale omgangsformer og betingelser for læring (Meld. St. 28 (2015-2016). (2016).)

Det følgende vil trekke frem noen konkrete formuleringer fra ny generell del av læreplanen, for å belyse og knytte til diskusjonen over. Overordnet del - verdier og prinsipper for grunnopplaeringen er nytt navn på generell del av læreplanen, som ble publisert i september 2017. Den bærer også i seg resultatet av en debatt som foregikk på regjeringens nettsider, nygenerelldel.regjeringen.no, i forkant, om hvilke tilføringer som måtte inn for å bli et styringsdokument av vår tid. Punktene jeg viser til under er det som ble igjen av en engasjert og nyansert nettdebatt, og skal svare utfordringene med dagens digitale kommunikasjonsteknologi og endrede sosiale omgangsformer og regler.

Dokumentets kapittel 1.3 om kritisk tenkning og etisk bevissthet sier: «Kritisk tenkning og etisk bevissthet er både en forutsetning for og en del av det å lære i mange ulike sammenhenger, og bidrar til at elevene utvikler god dømmekraft. Praktisk yrkesutøvelse og kunstnerisk arbeid krever også evne til å reflektere og gjøre vurderinger» (Kunnskapsdepartementet, 2017, p. 7). Det pekes på noen underliggende verdier for refleksjon og vurderingsevne som er viktig, både i utdanning, i yrkesutøvelse og for en mer og mer digital kommunikasjonsform. Formuleringene mangler å kobles til dømmekraft som er nødvendig i en digital tid, og en presisering av hvordan den teknologiske utviklingen påvirker hva det er behov for i dagens undervisning.

Kapittel 2.1 Sosial laring og utvikling er et punkt hvor teknologi settes i sammenheng med respekt for personvern: «God dømmekraft hos den enkelte er nødvendig for å ivareta personvern og respekt for privatlivet. (...) Ulike kommunikasjonsformer og bruk av teknologi både beriker og utfordrer det sosiale miljøet. Elevene må lære seg å opptre ansvarlig i alle sammenhenger i og utenfor skolen» (Kunnskapsdepartementet, 2017, p. 11). Åndsverk og opphavsrett er i likhet med personvern viktige faktorer, spesielt her hvor en overordnet del skal reflektere endringer i samfunnet, men opphavsrett og åndsverk nevnes aldri.

Videre i kapittel 2, punkt 2.5.3, Barekraftig utvikling, formuleres noe som kan tolkes i retning av 'å ruste elevene for den teknologiske utviklingen. Siste avsnitt tar opp teknologiens betydning for menneske og samfunn: «Teknologiutvikling kan bidra til å løse problemer, men kan også skape nye. Kunnskap om teknologi innebærer en forståelse av hvilke dilemmaer som kan oppstå ved bruk av teknologi, og hvordan disse kan håndteres» (Kunnskapsdepartementet, 2017, p. 14). Kapitlet gir en åpning for å drøfte etiske dilemmaer, for eksempel ved bruk av digitale verktøy. Her ville en formulering som ikke bare nevner kunnskap om ny teknologi, men som også problematiserer hvordan den brukes, ha åpnet opp for et mer konkret perspektiv på bærekraftig utvikling.

Formuleringene i ny overordnet del er på mange måter slik som i tidligere generell del (Kirke, utdannings- og forskningsdepartementet, 1993) svært vide, for å leses inn og tilpasses den bestemte læreplan for hvert enkelt fag. Den trekker mer konkret inn enn tidligere at det eksisterer ny teknologi, og at vi trenger kunnskap for å håndtere det som følger med denne.

\section{Treghet i skolepedagogiske danningsideal}

Det kan være interessant å se til tidligere skolepedagogiske danningsideal, også før digitale medium fikk den plass de har i dagens skole. Ulike kunstpedagogiske filosofier har styrt hvordan skolen forstår barns uttrykksevne, og hvordan den påvirkes av de visuelle medium som omgir oss. Med boken Kreativitet og vakst (1973) hadde Viktor Lowenfeld og William Lambert Brittain særlig innflytelse på tegneundervisningen i skolen. Tegning skulle stimulere 
barn til å utvikle sitt eget uttrykk, ikke kopiere meningsløse former (Lowenfeld \& Brittain, 1973, p. 32). Et slikt læringssyn er med tiden moderert noe, men har likevel vært førende i norsk lærerutdanning frem til midten av 1990-tallet (Nielsen, 2000). Den tydeligste holdningen, at etterligning og kopiering av visuelle former bryter mot kreativitetskonseptet, står fremdeles sterkt i det norske offentlige grunnskolesystemet i dag (Frisch, 2018, p. 11).

Lowenfeld og Brittains kunstpedagogiske syn ble problematisert allerede av Christer Romilson og Gert Z. Nordström med boken Skolen, bildet og samfunnet (Romilson \& Nordström, 1978), hvor de vektla kraften mediebilder hadde på verden i 70-årene. Her ble blant annet mediebildet brukt for å diskutere hvordan det vi ser preger utvikling av eget uttrykk. Et av budskapene var at vi ved å være bevisst medienes påvirkning, også vil bli bevisst hvordan de farger vår egen uttrykksevne. Skolen er ikke et unntak. Hvordan elevene velger å uttrykke seg blir farget av det som allerede eksisterer i deres visuelle verden. I dag er bilder allestedsnærværende, i sosiale medier, i massemedier, og over alt i det offentlige rom. Hovedforskjellen mellom 70-årene og nå er at tilbud og tilgjengelighet er enormt mye større med en digital delingskultur, og at mulighetene til å skape og gjøre det tilgjengelig for andre igjen er både lett og fristende.

\section{Avslutning}

Artikkelen har åpnet opp noe av kompleksiteten i åndsverkloven, og brettet ut ulike temaer som har betydning $\mathrm{i}$ en visuell og digital tid. Den har vist ulike eksempler for å konkretisere utfordringer og drøfte hva slags kunnskap som er nødvendig for å være informerte, kritiske og ansvarlige aktører $\mathrm{i}$ en digital delingskultur.

Det kan problematiseres om de store mesterverkene trivialiseres hvis de kan manipuleres og reproduseres av hvem som helst. Mulighetene vi nå har til å bearbeide eksisterende verk kan være en metode for å gjøre alle mennesker fortrolige med kunstverk. Når verk og motiver kan kjennes igjen i ulike sammenhenger er det kanskje en berikelse av vår felles kulturarv. Det intertekstuelle, som er foreslått oversatt til det interpikturelle, har nettopp denne dimensjonen at det spiller på uttrykk som vi kjenner igjen, og flytter det inn i en ny sammenheng, og ny visuell helhet uten å redusere originalverket. På platecoveret til Kind of Bloop er det originale fotografiet forenklet og remikset med teknokulturens pikselsymbolikk, og på denne måten plassert inn i en ny kontekst i en digital tid. Datamaskinen har fungert som verktøy for å mikse musikken, og det er datamaskinens grunnleggende system for å skape bilder med piksler som også spiller på et motiv vi kjenner igjen.

$\AA$ bruke allerede eksisterende verk er avgjørende for en kommunikasjonsform som remiks og appropriasjon. Denne uttrykksformen trekker tungt på de kulturelle referansene et verk allerede bærer for å skape mening. Verkene skaper nye beretninger ved å minne oss om de gamle. Det digitale mediet oppfordrer til eksperimentering, og flytter grenser. Det er en kanal for et vidt spekter av ytringer, og vil man formidle noe er det virkningsfullt å trekke inn gjenkjennelige elementer. Selv om det ikke er et godt nok argument at man skal kunne utnytte andres kreative innsats bare fordi teknologien gjør det enkelt å stjele, vil, i motsetning til det å misbruke andres åndsinnsats, den bevisste kopien, eller lånet eller leken med et verk, innebære en ny stemme som sammen med det vi kjenner igjen kan gi et mer polyfont kunstverk.

Utøvere innen forskjellige kunstneriske retninger, som musikere, forfattere, fotografer, billedkunstnere m.fl. kan oppleve loven som et hinder i sin egen kunstneriske utfoldelse, men samtidig er det ønskelig med makt til å hindre andre. I en skapende prosess der frihet er viktig kan altså åndsverkloven kjennes begrensende. Men i motsatt fall, når andre tar seg friheter og ens eget åndsverk blir kopiert, da kan den samme loven oppleves som noe positivt. Det oppstår her en dikotomi mellom lovens begrensende og beskyttende virkning, og i en skapende prosess er begge sider viktige.

I en skapende prosess, der andres verk er selve fargepaletten, kreves det en ekstra bevissthet på hvilke etiske valg man må reflektere over. For å unngå å krenke noens opphavsrett kan en løsning være å ikke bruke opphavsrettsbeskyttede bilder, eller kun publisere arbeider på 
lukkede områder. Men med en slik løsning lærer vi ikke å håndtere kompleksiteten som er viktig for å være deltagende i en digital delingskultur. Kanskje skepsisen for å bruke materiale fra vår felles kulturarv baseres på en overdreven redsel for å begå en kriminell handling. I en digital delingskultur deler vi, og vi blir delt. Til ett og samme verk kan det nå finnes opphavspersoner fra alle verdens land, deres møtepunkter eksisterer i en virtuell verden, og begrepet original har ikke lenger samme betydning.

Jeg har med artikkelen brettet ut problemstillinger knyttet til opphavsrett i fagfeltet kunst og håndverk, og peker samtidig på mangler som bør vies mer oppmerksomhet hvis lærere skal kunne bygge undervisning som reflekterer og forstår utfordringene $\mathrm{i}$ en visuell delingskultur. Sterkere fokus på hvordan andres bilder kan og ikke kan brukes vil innebære et behov for å virkelig forstå prinsippene som åndsverkloven bygger på. Praksisnær forskning $\mathrm{i}$ kunst og håndverksfaget, som for eksempel kan studere refleksjonsutviklende undervisningsformer, kan sette temaene på dagsorden både i grunnskolen og i lærerutdanningen, og utvikle lærernes faglige argumentasjon når de underviser om og med eksisterende verk.

\section{Silje Bergman}

PhD kandidat

Fakultet for humaniora, idretts- og utdanningsvitenskap

Institutt for estetiske fag, Universitetet i Sørøst-Norge

silje.bergman@usn.no 


\section{Referanser}

11-1197-2d-Cir. (2013). Cariou v. Prince, United States Court of Appeals for The Second Circuit. Retrieved from https://aw.justia.com/cases/federal/appellate-courts/ca2/11-1197/11-1197-2013-04-25.html

17-USC. Copyright Law of the United States 17 USC § 107- Limitations on exclusive rights: Fair use. Retrieved from https://www.copyright.gov/title17/92chap1.html\#107

Aktulum, K. (2011). Interpicturality In Braun-Vega's Paintings. Art-e Sanat Dergisi, 3(6). Retrieved from https://dergipark.org.tr/tr/pub/sduarte/issue/20725/221455

Aufderheide, P. (2013). Why Andy Baio's ‘Kind of Bloop' Copyright Case Shouldn't Dissuade Fair Use. Retrieved from http://mediashift.org/2013/06/fair-use-fearmongering-coming-from-friends/

Aufderheide, P., Jaszi, P. (2011). Reclaiming Fair Use. Chicago: The University of Chicago Press.

Baio, A. (2009a). Kind of Bloop - An 8-bit tribute to Miles Davis. Retrieved from https://www.kickstarter.com/projects/waxpancake/kind-of-bloop-an-8-bit-tribute-to-milesdavis?ref $=$ nav_search\&result $=$ project\&term $=$ kind $\% 20$ of $\% 20$ bloop

Baio, A. (2009b). Various, Kind of Bloop: An 8-Bit Tribute to Miles Davis'Kind of Blue. Retrieved from https://www.buzzfeed.com/benjaminj4/why-remix-culture-needs-new-copyrightlaws?utm_term=.qqMLR3Qq3y\#.qrlxJDebDz

Bergman, S. (2012). Ulike perspektiver på åndsverkloven. Gråsonen mellom kopiering og nyskapelse i visuell kunst. (Masteravhandling), Høgskolen i Oslo og Akershus, Oslo.

Brænne, K. (2009). Mellom ord og handling, Om verdsetjing i kunst og handverksfaget. (Doktoravhandling, Arkitektur- og designhøgskolen i Oslo) http://hdl.handle.net/11250/2406784

Caroll, M. W. (2007). Fixing Fair Use. North Carolina Law Review, 85(4) 1087-1154.

Crews, K. D. (2015). Fair Use Checklist. Retrieved from https://copyright.columbia.edu/content/dam/copyright/Precedent\%20Docs/fairusechecklist.pdf

DelRett.no. (2017). Hvem har ansvaret hvis en elev publiserer vernet materiale på nett? Retrieved from http://delrett.no/nb/sporsmal/hvem-har-ansvaret-hvis-en-elev-publiserer-vernet-materiale-på-nett-0

Duedahl, P., \& Jacobsen, M. H. (2010). Introduktion til dokumentanalyse. Odense: Syddansk Universitetsforlag.

Evans, W. (1936). Allie Mae Burroughs, Hale County, Alabama. Retrieved from https://www.metmuseum.org/art/collection/search/275876

FN. (1948). Verdenserklaeringen for menneskerettigheter. Retrieved from https://www.fn.no/OmFN/Avtaler/Menneskerettigheter/FNs-verdenserklaering-om-menneskerettigheter

Frisch, N. (2018). Modelling as a fundament for creativity. FormAkademisk-Forskningstidsskrift for design og designdidaktikk, 11(3). doi: https://doi.org/10.7577/formakademisk.2673

Goldsmith, K. (2011). Uncreative Writing: Managing Language in the Digital Age. New York: Columbia University Press.

Hagen, A. V. d. (2004, 3. desember). Digital dannelse. Morgenbladet. Retrieved from https://morgenbladet.no/2004/digital_dannelse

Hannemyr, G. (2017). 2. Grunnprinsippene. Retrieved from https://hannemyr.com/faq/legal_dm02.shtml\#basic

HR-2017-2165-A. (2017). Il Tempo Gigante. Norges Høyesterett Retrieved from https://lovdata.no/dokument/HRSIV/avgjorelse/hr-2017-2165-a

Haakonsen, P. (2017). Grunnleggende ferdigheter i kunst og håndverk. FORM, (3), 10-11.

Jackson, B. (2012). Why Remix Culture Needs New Copyright Laws. Retrieved from https://www.buzzfeed.com/benjaminj4/why-remix-culture-needs-new-copyrightlaws?utm_term=.rsnj6En3M5\#.sb854VpAaN

Jahr, H. D., \& Jahr, E. (2010). Maleri-malera. FORM - tidsskrift for kunst og design. (2), 22-23.

Johannessen, L., Rafoss, Tore Witsø, Rasmussen, Erik Børve. (2018). Hvordan bruke teori? Nyttige verktøy $i$ kvalitativ analyse. Oslo: Universitetsforlaget.

Jugacaro. (2014). Fondolvgiy. Retrieved from https:/www.flickr.com/photos/xrverde/12231049414/ 
Kirke, utdannings- og forskningsdepartementet. (1993). Læreplan for grunnskole, videregående opplæring, voksenopplæring: Generell del. Oslo: KUF.

Kristeva, J. (1980). Desire in Language: A Semiotic Approach to Literature and Art (T. Gora, Trans. L. S. Roudiez Ed.). New York: Columbia University Press.

Kulturdepartementet. (2016-2017). Lov om opphavsrett til åndsverk mv. (åndsverkloven). (Prop. 104 L (20162017)). Retrieved from https://www.regjeringen.no/no/dokumenter/prop.-104-120162017/id2547943/sec1

Kunnskapsdepartementet. (2017). Overordnet del-verdier og prinsipper for grunnopplaringen. Retrieved from https://www.regjeringen.no/no/dokumenter/verdier-og-prinsipper-for-grunnopplaringen/id2570003/

Lamb, B. (2007). Dr. Mashup or, Why Educators Should Learn to Stop Worrying and Love the Remix. EDUCAUSE Review 42(4), 12-25.

Lessig, L. (Writer). (2007). Larry Lessig on laws that choke creativity. In TED Talk. Retrieved from https://www.ted.com/talks/larry_lessig_says_the_law_is_strangling_creativity?language=en

Lessig, L. (2008). Making Art and Commerce Thrive in the Hybrid Economy. New York: The Penguin Press.

Levine, S. (1981). After Walker Evans: 4. Retrieved from https://www.metmuseum.org/art/collection/search/267214

Lowenfeld, V., \& Brittain, W. L. (1973). Kreativitet og vaekst. København: Gjellerup.

Lutnæs, E. (2011). Standpunktvurdering i grunnskolefaget kunst og håndverk. (Doktoravhandling, Arkitektur- og designhøgskolen i Oslo). Retrieved from http://hdl.handle.net/11250/93051

Løvlie, L. (2003). Teknokulturell danning. In O. Korsgaard, L. Løvlie, \& R. Slagstad (Eds.), Dannelsens fovandlinger. (347-371) Oslo: Pax Forlag.

Meld. St. 20 (2012-2013). (2013). På rett vei. Retrieved from https://www.regjeringen.no/no/dokumenter/meld-st20-20122013/id717308/sec4

Meld. St. 28 (2015-2016). (2016). Fag - Fordypning - Forståelse - En fornyelse av Kunnskapsløftet. Retrieved from https:/www.regjeringen.no/no/dokumenter/meld.-st.-28-20152016/id2483955/sec3\%23KAP3-2

NESH. (2016). Forskningsetiske retningslinjer for samfunnsvitenskap, humaniora, juss og teologi. Oslo: De nasjonale forskningsetiske komiteene. https://www.etikkom.no/globalassets/documents/publikasjonersom-pdf/60125_fek_retningslinjer_nesh_digital.pdf

Nielsen, L. (2000). Drawing and spacial representation. (Doktoravhandling), Oslo School of Architecture, Oslo.

Nordell, P. J. (1997). Rätten till det visuella. (Doktoravhandling), Juridiska institutionen, Stockholms universitet, Stockholm.

Osdal, M. (2014). Retten til eget bilde etter åndsverkloven $\S 45 \mathrm{c}$ - Privatpersoners vern i sammenheng med andre privatpersoners publiseringer på sosiale medier. (Masterthesis), Universitetet i Oslo, Oslo. Retrieved from https://www.duo.uio.no/handle/10852/42841?show=full

Perloff, M. (2010). Unoriginal Genius: Poetry by Other Means in the New Century. Chicago: University of Chicago Press.

Rognstad, O. A., \& Lassen, B. S. (2009). Opphavsrett. Oslo: Universitetsforlaget.

Romilson, C., \& Nordström, G. Z. (1978). Skolen, bildet og samfunnet. Oslo: Pax Forlag.

Rostama, G. (2015). Remix Culture and Amateur Creativity: A Copyright Dilemma. WIPO magazine (3) 22-25. https://www.wipo.int/export/sites/www/wipo_magazine/en/pdf/2015/wipo_pub_121_2015_03.pdf

Skadeserstatningsloven. (1969). Lov om skadeserstatning. Retrieved from https://lovdata.no/dokument/NL/lov/1969-06-13-26

Stana, I. (2017). Opphavsrett i klasserommet. FORM, (5) 12-13.

Svendsen, L. F. (2012). Kunst: en begrepsavvikling. Oslo: Universitetsforlaget.

Torvund, O. (2012). Når et verk faller i det fri. Retrieved from https://blogg.torvund.net/2012/01/10/nar-et-verkfaller-i-det-fri/

Torvund, O. (2017). Verner opphavsretten for mye? Retrieved from https://www.torvund.net/index.php?page $=$ opph_vrnformye 
Utdanningsdirektoratet. (2012). Rammeverk for grunnleggende ferdigheter. Retrieved from https://www.udir.no/globalassets/upload/larerplaner/lareplangrupper/rammeverk_grf_2012.pdf

Veiteberg, J. (1982). Skaping eller gjenskaping. Nokre tolkingsproblem i samband med Lena Cronqvist sine bilete. Kunst og kultur, 66(2), 113-128.

Vik, S. (2009). Når kunst gjøres til kunst. Billedkunst, (5), 9.

Aakre, H. (2002). Retten til å sitere fra åndsverk. Bergen: Fagbokforlaget.

Åndsverkloven. (2018). Lov om opphavsrett til åndsverk. Retrieved from https://lovdata.no/dokument/NL/lov/2018-06-15-40?q=lov\%20om\%20opphavsrett\%20til\%20åndsverk 